\title{
LANDSCAPE MOVEMENTS BY TWO SPECIES OF MIGRATORY NECTAR-FEEDING BATS (LEPTONYCTERIS) IN A NORTHERN AREA OF SEASONAL SYMPATRY
}

\author{
Michael A. Bogan 1 , Paul M. Cryan 2,4 , Christa D. Weise ${ }^{3}$, and Ernest W. Valdez ${ }^{1}$
}

\begin{abstract}
Animals often migrate to exploit seasonally ephemeral food. Three species of nectar-feeding phyllostomid bats migrate north from Mexico into deserts of the United States each spring and summer to feed on blooms of columnar cactus and century plants (Agave spp.). However, the habitat needs of these important desert pollinators are poorly understood. We followed the nighttime movements of 2 species of long-nosed bats (Leptonycteris yerbabuenae and L. nivalis) in an area of late-summer sympatry at the northern edges of their migratory ranges. We radio-tracked bats in extreme southwestern New Mexico during 22 nights over 2 summers and acquired location estimates for 31 individuals. Both species cohabitated 2 major day roosts that were $30 \mathrm{~km}$ apart and in different mountain ranges, and individual bats sometimes moved between the roosts. Sampling was opportunistic and limited, but there were no obvious qualitative differences in observed patterns of movement between species or years, or among sex, age, and reproductive groups. Both species were observed foraging most often in the mountain range that had a relatively higher observed density of presumed food plants (Agave palmeri); when roosting in an adjacent mountain range, bats sometimes commuted $>20 \mathrm{~km}$ one way to forage. Contrary to evidence indicating these species partition resources farther south in Mexico, our findings suggest that L. yerbabuenae and L. nivalis seasonally share common roost and food resources during late summer in this northern area of sympatry.
\end{abstract}

Resumen.-A menudo, los animales migran en búsqueda de alimentos, propios de cada estación. Tres especies de murciélagos filostómidos que se alimentan de néctar migran cada primavera y verano, desde el norte de México hacia los desiertos de Estados Unidos para alimentarse de las floraciones de cactáceas columnares y de agaves americanos (Agave spp.). Sin embargo, las necesidades en relación al hábitat de estos importantes polinizadores del desierto son poco conocidas. Estudiamos los movimientos nocturnos de dos especies de murciélagos magueyeros (Leptonycteris yerbabuenae y L. nivalis) en una área de simpatría a finales del verano, en los límites norteños de sus rangos migratorios. Rastreamos murciélagos con radiotransmisores al extremo suroeste de Nuevo México durante 22 noches en dos veranos y estimamos los puntos de ubicación de 31 ejemplares. Ambas especies coexistieron en dos refugios principales separados por 30 kilómetros de distancia y en distintas cadenas montañosas. Sin embargo, en ocasiones, los murciélagos se trasladaron por sí solos de un refugio a otro. El muestreo fue oportunista y limitado, pero no hubo diferencias cualitativas evidentes en los patrones de movimiento observados entre las especies o los años, o entre el sexo, la edad y los grupos reproductivos. Ambas especies fueron observadas buscando alimento, con mayor frecuencia, en cadenas montañosas con una densidad relativamente más alta de plantas de las cuales se alimentan (Agave palmeri). Cuando descansan en una cadena montañosa adyacente, los murciélagos a veces viajan $>20 \mathrm{~km}$ unidireccionalmente en búsqueda de alimentos. Contrariamente a lo que indican las evidencias, de que estas especies reparten sus recursos más al sur en México, nuestros estudios sugieren que L. yerbabuenae y L. nivalis comparten estacionalmente los mismos recursos alimenticios y de descanso al final del verano en esta zona norteña de simpatría.

Migratory animals often move substantial distances to take advantage of food that is patchy in distribution and only available during certain times of year. Different migratory animals sometimes converge in time and space on ephemeral food resources to exploit limited periods of seasonal abundance, bringing related species into potential competition and making the sometimes risky strategy of migration even riskier (Baker 1978). This may be the case with nectar-feeding bats in the Desert Southwest of North America. In northern Mexico and the southwestern United States, many of the dominant flowering plants in desert ecosystems (e.g., columnar cactus and century plants [Agave spp.]) have mutualistic interactions with migratory bat pollinators, yet regionally these flowers may only be available for short periods of time (Gentry 1982, Nabhan and Fleming 1993, Fleming et al. 2001,

${ }^{1}$ U.S. Geological Survey, Fort Collins Science Center, Department of Biology, Albuquerque, NM 87131.

${ }^{2}$ U.S. Geological Survey, Fort Collins Science Center, 2150 Centre Ave., Bldg. C, Fort Collins, CO 80526

${ }^{3}$ U.S. Fish and Wildlife Service, Kofa National Wildlife Refuge, 9300 E. 28th St., Yuma, AZ 85364.

${ }^{4}$ Corresponding author. E-mail: cryanp@usgs.gov 


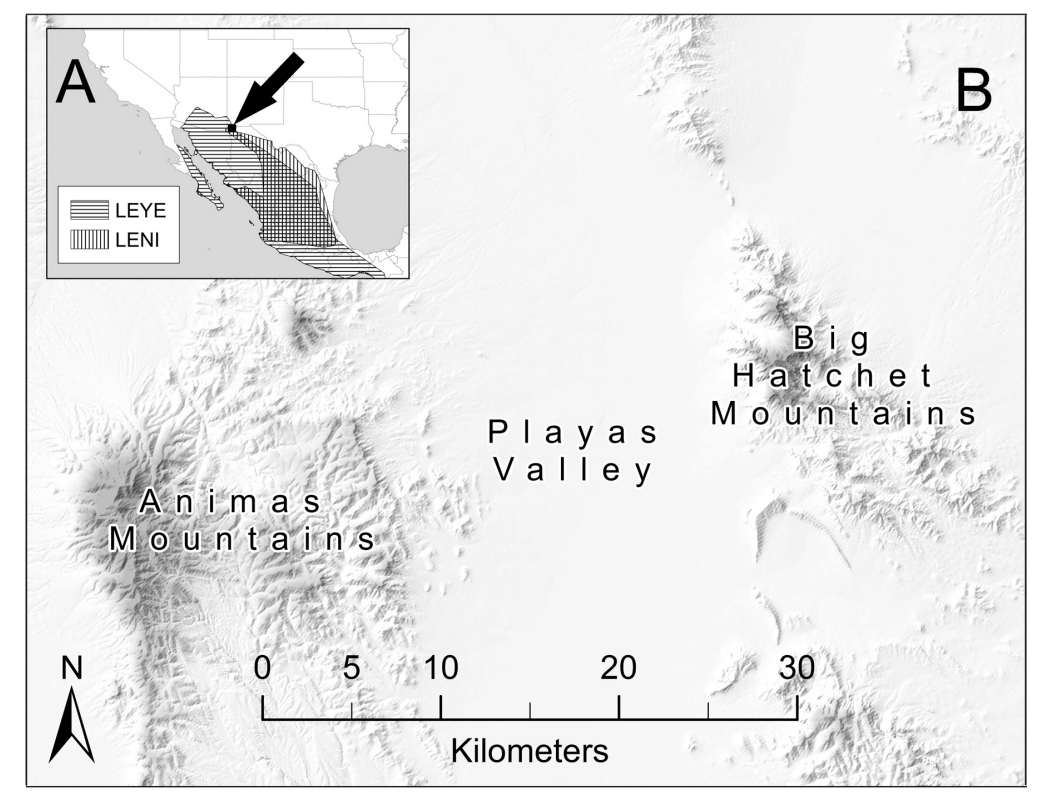

Fig. 1. Study area maps: (A) study area (black square with arrow) in Hidalgo Co., New Mexico, in relation to the overlapping distributions of Leptonycteris yerbabuenae (LEYE, horizontally hatched area) and L. nivalis (LENI, vertically hatched area); (B) topographic detail of study area where long-nosed bats were radio-tracked during the summers of 2004 and 2005 .

Valiente-Banuet 2002). Migratory pollinators are susceptible to resource variability and landscape changes, and nectar-feeding bats could be particularly vulnerable (Fleming 2004, Nabhan 2004, Holden 2006).

Three species of nectar-feeding bats migrate seasonally from Mexico into the southwestern United States to feed from, and in turn help pollinate, the ephemeral flowers of cactus and species of Agave. These bat species are the Mexican long-tongued bat (Choeronycteris mexicana), the lesser long-nosed bat (Leptonycteris yerbabuenae, formerly L. curasoae yerbabuenae; see Wilson and Reeder 2005, Cole and Wilson 2006), and the greater longnosed bat (L. nivalis). All 3 species are likely at risk of population declines, and both species of Leptonycteris are listed as endangered under the United States Endangered Species Act (O'Shea and Bogan 2003). This bat guild migrates northward from central and southern Mexico in spring and summer, perhaps along "nectar corridors" of flowering plants that provide a consistent, yet temporally and spatially variable, supply of nectar and pollen (Fleming 2004). Most of the long-nosed bats entering the southwestern United States during summer are believed to be reproductive females arriving to give birth or females accompanied by recently born young, implying that this region at the northern margins of the two species' ranges is important to reproduction and maintenance of viable populations (Fleming 2004, Cole and Wilson 2006, Medellín 2009).

Although the geographic distributions of L. yerbabuenae and L. nivalis overlap throughout much of their ranges in Mexico (Fig. 1A), the 2 species are thought to usually exploit different habitats where they co-occur (Baker and Cockrum 1966, Arita 1991, Ayala-Berdón et al. 2013), and in the United States, the species tend to migrate into different regions. Evidence to date indicates that during spring L. yerbabuenae moves into southeastern Arizona and southwestern New Mexico via a possible route along the western flanks of the Sierra Madre Occidental to reach transient roosts in those states, whereas individuals arriving to form large maternity colonies in southwestern Arizona might migrate along the coastal lowlands of western Mexico (Wilkinson and Fleming 1996, Fleming et al. 2003). Later in summer, some postreproductive female bats from southwestern Arizona may move eastward into southeastern Arizona, and perhaps 
New Mexico, to areas where species of Agave are still abundantly flowering (Cockrum 1991, Hoyt et al. 1994). Migration movements of $L$. nivalis are different than $L$. yerbabuenae (Moreno-Valdez et al. 2000, 2004). In the United States, L. nivalis might migrate along the Sierra Madre Oriental and is only known to seasonally occupy a single cave in Texas during midsummer (mid-June through midAugust; Ammerman et al. 2009, 2012). During late summer (mid-July through September), L. nivalis occupies 2 caves in the Big Hatchet and Animas mountains of southwestern New Mexico, which were the focus of this study. The arrival of both species of long-nosed bats to southern New Mexico during late summer coincides with the regional flowering of Agave (Cockrum 1991, Fleming et al. 2003), especially A. palmeri, coupled with senescence of blooms in other northern parts of their ranges. In New Mexico, Texas, and Chihuahua, as far as is known, long-nosed bats depend heavily on flowers of Agave, which tend to bloom from mid to late summer (Gentry 1982, Hensley and Wilkins 1988). In Arizona and Sonora, L. yerbabuenae also obtains nectar and pollen produced by flowers of columnar cactus, which mostly bloom during spring and early summer (Fleming et al. 2001). In this study, we investigated 2 species of long-nosed bats that are believed to use different habitats elsewhere in their ranges where they co-occur. We aimed to better understand how these species use common food and roost resources by following the nighttime movements of individuals in an area where they seasonally co-occur.

\section{Methods}

\section{Study Area}

New Mexico is unique among the southwestern states of the United States in having both species of Leptonycteris seasonally cooccur during the summer months (Findley et al. 1975, Hoyt et al. 1994, Cryan and Bogan 2003). Only L. yerbabuenae is known to occur in Arizona (Hoffmeister 1986) and only $L$. nivalis is documented in Texas (Ammerman et al. 2012). The study area thus represents an area of sympatry at the northern edges of the migratory ranges of $L$. yerbabuenae and L. nivalis (Fig. 1A). The Animas Mountains in the western half of our study area represent the westernmost distribution of $L$. nivalis in the United States, while the Big Hatchet Mountains in the eastern half of our study area represent the easternmost distribution of L. yerbabuenae in the United States.

We radio-tracked long-nosed bats for 2 approximately 2-week periods during the summers of 2004 and 2005 in southern Hidalgo County, New Mexico (Fig. 1B). We worked from approximately mid-July to mid-August each year, a season of peak occurrence for Leptonycteris in the region (Hoyt et al. 1994). We initially focused our efforts in the Animas Mountains where we knew of a roost cave occupied by both species, but then expanded into the adjacent Playas Valley and Big Hatchet Mountains after we better discerned bat movements and discovered a major roost cave in the latter range (Fig. 1B). The study area was approximately $38 \times 38 \mathrm{~km}$ or $1444 \mathrm{~km}^{2}$ and was bounded by the following coordinates: north $108.60^{\circ} \mathrm{E}, 31.70^{\circ} \mathrm{N}$; south $108.60^{\circ} \mathrm{E}$, $31.44^{\circ} \mathrm{N}$; east $108.33^{\circ} \mathrm{E}, 31.56^{\circ} \mathrm{N}$; and west $108.80^{\circ} \mathrm{E}, 31.56^{\circ} \mathrm{N}$. The Animas and Big Hatchet mountains and the intervening Playas Valley belong to the Basin and Range Province of western North America. Semidesert grasslands dominated most of the study area, with Madrean Evergreen Woodland (a mixture of alligator bark juniper, piñon, Chihuahua pine, and species of oak), lower Interior Chaparral (manzanita, mountain mahogany), and Interior Southwest Riparian Deciduous Forest (sycamore, cottonwood, and rabbitbrush-Apache plume) occurring in patches at higher elevations (Brown 1994). The highest elevations in the Animas Mountains (generally above where we worked) had small areas of Rocky Mountain (Petran) Montane Conifer Forest (ponderosa pine, aspen, and Douglas-fir; Brown 1994). Chihuahuan desert scrub covered the Playas Valley, with creosote bush and ocotillo on the bajadas and mesquite and saline-adapted shrubs on the alluvial floor (Brown 1994).

The main food resource of long-nosed bats in New Mexico is suspected to be Agave palmeri (Ober and Steidl 2004, Scott 2004). This species of century plant is widely distributed across oak woodlands and grama grasslands in the Desert Southwest (Gentry 1982). Our observations while conducting fieldwork suggested that patches of A. palmeri were relatively dense on rocky, precipitous slopes in the Animas Mountains, whereas we 
saw fewer such patches that also seemed less dense where we worked on the western flank of the Big Hatchet Mountains; proportionally few A. palmeri were observed growing in the Playas Valley.

\section{Bat Capture and Tagging}

We netted bats at 2 sites in the Animas Mountains during 2004 and 2005 where longnosed bats had been previously captured (Hoyt et al. 1994). Bats were captured in mist nets placed near night roosts and in known flyways (Hoyt et al. 1994) using standard methods (Kunz et al. 2009). Nets were monitored continuously and bats were removed immediately upon detection, placed in separate cloth bags, and kept in a quiet, dark area until data were collected. Bats were usually held for $<10 \mathrm{~min}$, the exceptions being those held approximately $45 \mathrm{~min}$ for radio-tagging. All bats were released unharmed as soon as data were collected. For each bat captured we recorded species, sex, age, weight, and reproductive status. Species of Leptonycteris were differentiated using a combination of criteria (following Hoffmeister 1986, Hoyt et al. 1994, and our own observations): length of forearm, length of terminal phalanx of the third finger, and length and density of fur. Bats were identified as L. yerbabuenae if the forearm measured 52-56 $\mathrm{mm}$, the terminal phalanx of the third finger measured 9-15 $\mathrm{mm}$, the pelage was relatively short and dense, and if there was no distinct margin of protruding hairs at the edge of the uropatagium. Bats were identified as L. nivalis if the forearm measured $52-60 \mathrm{~mm}$, the terminal phalanx of the third finger measured $17-19 \mathrm{~mm}$, the pelage was relatively long, and if there was a distinct fringe of hair along the edge of the uropatagium.

We determined whether bats were adults or young-of-year by examining the backlit finger joints of the wing. Bats exhibiting joints with translucent, cylindrical, cartilaginous epiphyses were classified as young-of-year, whereas all others were considered adults (Brunet-Rossinni and Wilkinson 2009). Because the joints of young bats ossify fairly quickly and the timing of our work was late in the summer, it is possible that some individuals we characterized as adults were young-of-year. We classified female bats as lactating if they exhibited sparse pelage around enlarged nipples and if milk could be expressed, postlactating if they had sparse pelage but no milk, and nonreproductive if the pelage around the nipples was complete (Racey 2009). Male bats were classified as reproductive if enlarged epididymes were observed (Racey 2009). Because we did not permanently mark bats, it was possible that individuals were tagged during both years.

\section{Radiotelemetry}

Select bats captured during 2004 and 2005 were tagged for tracking using miniature radio transmitters (Holohil Systems Ltd., Woodlawn, Ontario, Canada; Blackburn Transmitters, Nacogdoches, Texas). Radio transmitters weighed between 0.53 and $0.78 \mathrm{~g}$, which was always less than the recommended maximum of $5 \%$ of the bat's body weight (Aldridge and Brigham 1988). Transmitters were attached to the midscapular region of the dorsal pelage using surgical adhesive (Skin-Bond, Smith and Nephew, Largo, FL) after trimming a small patch of fur to within $1 \mathrm{~mm}$ of the skin. To ensure adhesion, bats were held for $30 \mathrm{~min}$ after transmitter attachment. All capture, handling, and radio-tagging of bats was done under the auspices of U.S. Fish and Wildlife Service endangered species permits and New Mexico scientific collecting permits, and followed best practices of the American Society of Mammalogists (Sikes et al. 2011) and specific protocols approved by the Institutional Animal Care and Use Committee of the USGS Fort Collins Science Center.

During July and August of 2004 (13 nights) and 2005 (15 nights), we attempted to continuously monitor for signals of marked bats from dusk to dawn using fixed telemetry stations. Stations were initially situated only on mountain peaks or prominent topographic features, such as ridges and escarpments, but we subsequently also tracked from lower-elevation stations in the valley to better characterize unanticipated bat movements (Fig. 2A). Each station was operated by 2 people who alternated monitoring duties throughout the night. On a typical night, we operated between 3 and 5 stations. At each station, we tracked bats using a pole-mounted, 5-element Yagi antenna attached to a scanning telemetry receiver (R-1000, Communication Specialists, Inc., Orange, CA). Antennas were mounted on top of $2-\mathrm{m}$ poles set in a swiveling tripod base, and the antenna elements were oriented 


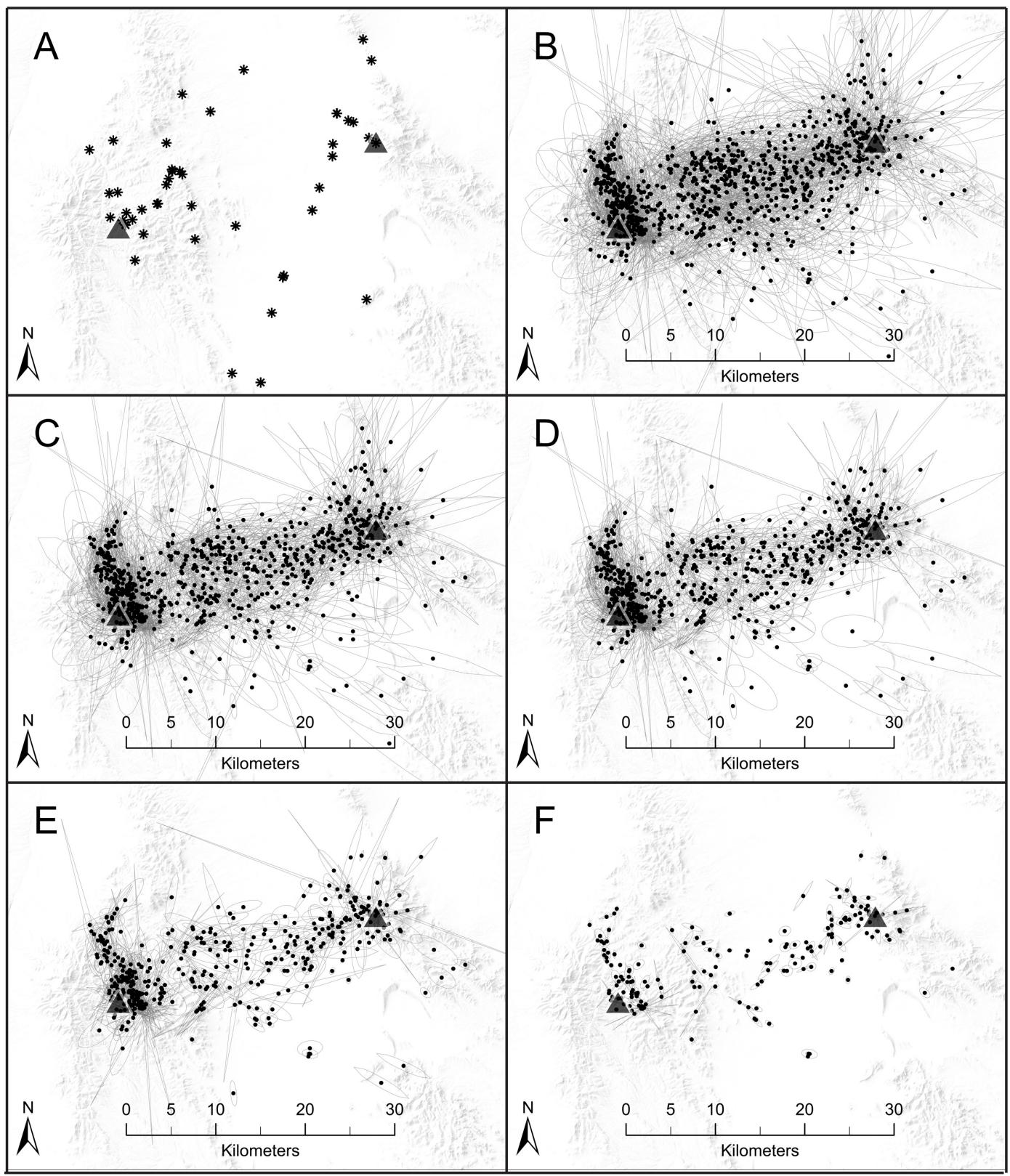

Fig. 2. Radio-tracking stations and locations of Leptonycteris estimated from radiotelemetry data collected in mid-July through August of 2004 and 2005. (A) Asterisks show locations of radiotelemetry tracking stations used during the study. Black circles in panels B-F represent location estimates, and surrounding ellipses (light gray lines) represent $95 \%$ confidence areas for each location estimate. Panels display different levels of error: (B) error areas $\leq 100 \mathrm{~km}^{2} ;(\mathrm{C}) \leq 50 \mathrm{~km}^{2}$; (D) $\leq 25 \mathrm{~km}^{2} ;(\mathrm{E}) \leq 10 \mathrm{~km}^{2} ;(\mathrm{F}) \leq 1 \mathrm{~km}^{2}$. We qualitatively chose estimates with error $\leq 10 \mathrm{~km}^{2}$, which is sufficiently precise for inferring bat movement patterns. Triangles show general locations of caves used as daytime roosts.

parallel to the ground. Each pole was fitted with a mounted compass that allowed the tracker to take precise bearings on signal peaks without having to put down the antenna. In addition to tracking stations, we established a nightly base station that coordinated and facilitated all tracking activity. Tracking crews were in contact with each other and with the base station via 2 -way communication radios. Headphones were not used for tracking because 
they interfered with radio communication among stations.

We used the following protocol for each night of tracking. After arriving at a tracking station, each member of the crew took bearings on 3 to 6 "beacon" transmitters that we had previously placed throughout the study area. Additionally, a Global Positioning System (GPS) unit was used to record the exact coordinates of the tracking station ( \pm 5 to $10 \mathrm{~m}$ ). These bearings were called into the base station where they were checked against known bearings derived from cartographic software on a laptop computer. This step ensured that equipment was functioning properly each night and that tracking crews were taking accurate bearings.

Tracking began shortly after sunset and consisted of continuously scanning active transmitter frequencies of bats at 20-s intervals until a signal was detected. Immediately upon detection of a signal, the tracking station that detected it relayed the information (frequency and direction) to the base station and other tracking crews, as well as recorded the information on its own tracking datasheet. From that point forward, the other tracking stations tuned to the detected transmitter frequency and scanned for a signal. Any station that detected a signal would then take 3 simultaneous bearings at the start of every subsequent minute for $3 \mathrm{~min}$. After $3 \mathrm{~min}$ of monitoring that frequency, stations returned to scanning for other frequencies, unless directed otherwise by the base station. Watches were synchronized regularly to ensure that bearings were recorded simultaneously. Monitoring continued until dawn, with tracking crews typically alternating duties every 2 to $4 \mathrm{~h}$. Monitoring was suspended during periods of heavy rain, strong winds, and lightning, but continued when such conditions subsided. When radio signals were suddenly detected or lost near the location of a known roost, we assumed those individual bats were exiting or entering the roost, respectively, because radio signals were blocked by caves and other roost structures.

Our original plan was to systematically follow the radio signals of individual bats by using the same nightly tracking stations in the Animas Mountains, then quantify habitat use (e.g., home range and core use areas) only in that area. However, after the first few nights of tracking, it became clear that bats were often leaving eastward beyond the areas where we could detect them with our tracking stations in the Animas Mountains. Bats often flew such long distances that it became impractical to situate tracking stations such that we could obtain consistent and precise location estimates for individuals transiting the entire study area during a given night. Therefore, we decided to focus on characterizing the extent of bat movements in the greater region and began regularly moving tracking stations to better determine areas of regular bat activity. Because of this, our resultant sampling was haphazard and opportunistic. A more systematic sampling strategy (e.g., fixed-interval scans from nonmoving stations) was not practical, because signal detection varied greatly across the study area and bats moved long distances, making it very difficult to simultaneously detect a consistent signal from multiple stations. These sampling limitations, combined with fairly small sample sizes of each species, sex, age, and reproductive class, influenced us to hereafter treat these data qualitatively rather than quantitatively, with the exception of calculating error of location estimates.

\section{Data Analysis}

We estimated bat locations from 2 or more simultaneous ( $\pm 5 \mathrm{~s}$ ) radio bearings. All locations were estimated using LOCATE II software, and $95 \%$ error ellipses were generated using the accompanying software GIS.exe (Nams 1990; https://www.dal.ca/faculty/agriculture/ plant-food-env/faculty-staff/our-faculty/ vilis-nams/locate-ii.html, accessed 2 June 2017). We set the LOCATE II program to estimate locations based on 3 or more bearings using Lenth's maximum likelihood estimation (MLE) technique (Lenth 1981a, 1981b, Nams and Boutin 1991). Locations derived from 2 bearings were estimated using a fixed standard deviation of 8.48. This fixed deviation value was calculated from error estimates generated from the MLE analysis of all positions based on 3 or more bearings $(n=661)$ using the following equation presented by Nams (1990):

$$
\text { fixed deviation value }=\sqrt{\frac{\sum S S}{\sum(N-1)}},
$$

where SS is the sum of squares from each location estimate and $N$ is the sample size 
TABLE 1. Tally of long-nosed bats $(n=31)$ successfully tracked during this study by year ('04 = 2004, '05 = 2005), average number of nights individuals were tracked, average number of location estimates (with error $\leq 10 \mathrm{~km}^{2}$ ) acquired per individual bat per night, and percentage of individuals detected in 3 general regions of the study area. Results are tabulated by species, sex, age, and reproductive class: $\mathrm{M}=$ male, $\mathrm{F}=$ female; $\mathrm{NR}=$ no signs of reproduction, $\mathrm{Y}=$ young-of-year, $\mathrm{L}=$ lactating, $\mathrm{PL}=$ post-lactating. The 3 general regions of the study area were the Animas Mountains, Playas Valley, and Big Hatchet Mountains (Fig. 1). Both species were concurrently tracked between 19 July and 10 August in 2004, then between 19 July and 9 August in 2005.

\begin{tabular}{|c|c|c|c|c|c|c|c|}
\hline \multirow[b]{2}{*}{ Species } & \multirow[b]{2}{*}{ Group } & \multirow[b]{2}{*}{$n$ ('04/'05) } & \multirow[b]{2}{*}{$\begin{array}{l}\text { Avg. } \\
\text { nights } \\
\text { tracked }\end{array}$} & \multirow[b]{2}{*}{$\begin{array}{l}\text { Avg. loc. } \\
\text { per bat } \\
\text { per night }\end{array}$} & \multicolumn{3}{|c|}{$\%$ Individuals detected by area } \\
\hline & & & & & $\begin{array}{l}\text { Animas } \\
\text { Mtns. }\end{array}$ & $\begin{array}{l}\text { Playas } \\
\text { Valley }\end{array}$ & $\begin{array}{c}\text { Big } \\
\text { Hatchet Mtns. }\end{array}$ \\
\hline L. yerbabuenae & $\begin{array}{l}\text { M (NR \& Y) } \\
F(N R \& Y) \\
F(L) \\
F(P L)\end{array}$ & $\begin{array}{l}1 / 2 \\
2 / 7 \\
1 / 0 \\
4 / 2 \\
8 / 11\end{array}$ & $\begin{array}{l}2.0 \\
2.7 \\
2.0 \\
3.0 \\
2.6\end{array}$ & $\begin{array}{r}5.0 \\
5.9 \\
13.5 \\
8.7 \\
6.9\end{array}$ & $\begin{array}{r}100 \% \\
44 \% \\
100 \% \\
83 \% \\
68 \%\end{array}$ & $\begin{array}{c}33 \% \\
100 \% \\
- \\
67 \% \\
74 \%\end{array}$ & $\begin{array}{c}33 \% \\
44 \% \\
- \\
33 \% \\
37 \%\end{array}$ \\
\hline L. nivalis & $\begin{array}{l}\text { M (NR) } \\
F(N R) \\
F(L) \\
F(P L)\end{array}$ & $\begin{array}{l}3 / 2 \\
0 / 0 \\
1 / 0 \\
5 / 1 \\
9 / 3\end{array}$ & $\begin{array}{l}1.6 \\
1.0 \\
1.3 \\
1.4\end{array}$ & $\begin{array}{l}3.0 \\
\overline{6.0} \\
6.6 \\
4.9\end{array}$ & $\begin{array}{r}40 \% \\
- \\
100 \% \\
67 \% \\
58 \%\end{array}$ & $\begin{array}{l}20 \% \\
- \\
50 \% \\
33 \%\end{array}$ & $\begin{array}{l}60 \% \\
- \\
- \\
17 \% \\
33 \%\end{array}$ \\
\hline TOTAL & & 31 & 1.7 & 6.4 & $65 \%$ & $58 \%$ & $35 \%$ \\
\hline
\end{tabular}

(number of bearings) for each location. We believe that this fixed error estimate was reasonable; average error of readings taken from beacons situated across the entire study area was $8.26(n=176)$.

Spatial analyses were carried out on maps in the Albers Equal Area Conic USGS projection (NAD83 datum). Time of each location, by hour after sunset, was calculated using the sunset calculator of the U.S. Naval Observatory, Astrological Applications Department (http://aa.usno.navy.mil/data/docs/RS_One Day.html, accessed 2 June 2017) with values derived for Lordsburg, New Mexico, which is the city nearest the study area. A geospatial data file containing our location estimates with associated information was made available by Bogan et al. (2017).

\section{RESULTS}

\section{Captures and Radio Telemetry}

We captured a total of $34 \mathrm{~L}$. yerbabuenae (13 adult females, 19 young-of-year, 2 adult males) and $25 \mathrm{~L}$. nivalis (15 adult females, 3 young-of-year, 7 adult males) in 2004 and 2005 . We attached radio transmitters to $27 \mathrm{~L}$. yerbabuenae and 19 L. nivalis, then obtained sufficiently precise location estimates $(\leq 10$ $\mathrm{km}^{2}$; see below) for $67 \%$ of them $(n=31$; Table 1). Both species were concurrently tracked between 19 July and 10 August in
2004, then between 19 July and 9 August in 2005. We discerned movements of 19 L. yerbabuenae, each tracked an average of 2.6 nights, and obtained an average of 6.9 location estimates per bat per night (Table 1). We followed 12 L. nivalis, with each bat tracked an average of 1.4 nights, and obtained an average of 4.9 location estimates per bat per night (Table 1). Three of the tagged bats (2 female L. yerbabuenae and 1 male L. nivalis) were not detected consistently enough to derive sufficiently precise location estimates. We suspect that the 13 bats we never detected after tagging $(7 \mathrm{~L}$. yerbabuenae and $6 \mathrm{~L}$. nivalis of various sex and age groups) either left the study area or removed their transmitters, or the radio transmitters malfunctioned.

Over 5000 person-hours of effort were spent tracking bats during the summers of 2004 and 2005 , involving more than $300 \mathrm{~h}$ of continuous tracking. Of the $>5000$ bearings taken during tracking efforts, 4834 were simultaneous with at least one other and were used in the estimation of 1293 bat locations. Bats flew throughout the night, although we observed a decrease in detection near the middle of the night in both species (Fig. 3). We estimated 640 locations using 2 bearings and 653 locations using $\geq 3$ bearings. The average number of bearings used per location estimate was 2.7. The size of error ellipses, which indicated the 95\% confidence area of location estimates, were variable: 


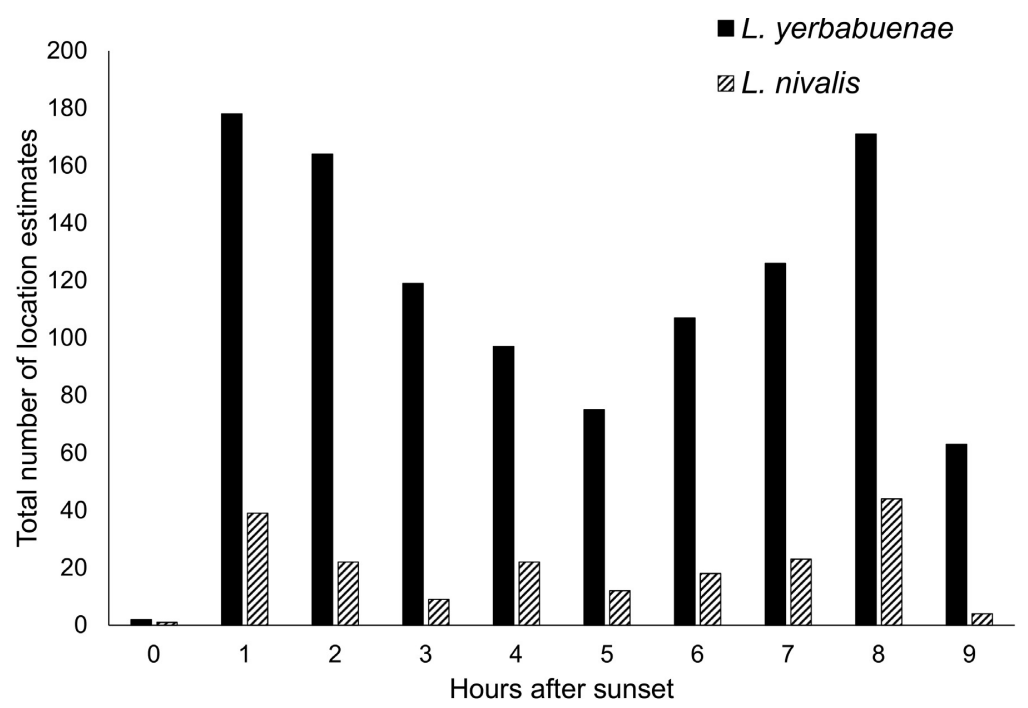

Fig. 3. Temporal nighttime patterns of radio detections, showing the total number of all radio location estimates $(n$ $=1296$ ) by hour after sunset. Solid bars represent location estimates for Leptonycteris yerbabuenae and striped bars represent those of L. nivalis. Decreases in the number of detections near the middle of the night were presumed to be associated with bats resting in roost structures that attenuated radio signals.

$70 \%(n=899)$ of estimates had error ellipses $\leq 100 \mathrm{~km}^{2}$ (Fig. 2B); 60\% $(n=771)$ had error ellipses $\leq 50 \mathrm{~km}^{2}$ (Fig. 2C); 48\% $(n=626)$ had error ellipses $\leq 25 \mathrm{~km}^{2}$ (Fig. 2D); 33\% $(n=425)$ had error ellipses $\leq 10 \mathrm{~km}^{2}$ (Fig. $2 \mathrm{E}$ ); and $13 \%$ $(n=172)$ had error ellipses $\leq 1 \mathrm{~km}^{2}$ (Fig. $\left.2 \mathrm{~F}\right)$. When examining the overall distribution of location estimates with error $\leq 10 \mathrm{~km}^{2}$, a level of error we judge to be sufficiently precise for representing bat movements relative to the broader landscape, we found no clear patterns between years (Fig. 4A), species (Fig. 4B), or sexes (Fig. 4C), or among age groups (Fig. 4D) or individuals (Fig. 4E).

Location estimates of individual bats, constructed using location estimates with error $\leq 10 \mathrm{~km}^{2}$, reveal that groups and individuals of both species were regularly active in the Animas and Big Hatchet mountains, as well as the intervening Playas Valley (Fig. 4A-E). Both species regularly roosted together during the day in the 2 known caves. Although tracking stations and initial efforts were concentrated in the Animas Mountains, we detected more than half of the radio-marked individuals using that range, regardless of species, whereas proportionally fewer individuals were detected around the Big Hatchet Mountains and Playas Valley (Table 1). Only 10\%-15\% of individuals we tracked had location estimates that were sufficiently precise to infer that the bats used both mountain ranges and the intervening valley. However, it was difficult to obtain consistently precise location estimates for bats traveling between mountain ranges on a given night. We often heard the signals of individuals moving from one mountain range to the other. In many of those cases, we could not get simultaneous fixes on rapidly moving bats because of limited numbers of tracking stations in each area and shorter detection distances associated with requisite low-elevation positioning of tracking stations in the Playas Valley. We were not able to quantify rates at which bats transited different regions of the study area, but our qualitative impression was that individuals of both species moved more rapidly and directly across the Playas Valley and generally did not dwell long in the Big Hatchet Mountains while being tracked.

\section{Discussion}

This was one of the first studies to focus on the fine-scale nightly movements of individual L. yerbabuenae and L. nivalis in an area of seasonal sympatry. Our observations demonstrate that both species of Leptonycteris regularly occur in the study area during late summer and exhibit superficially similar roosting and nightly 


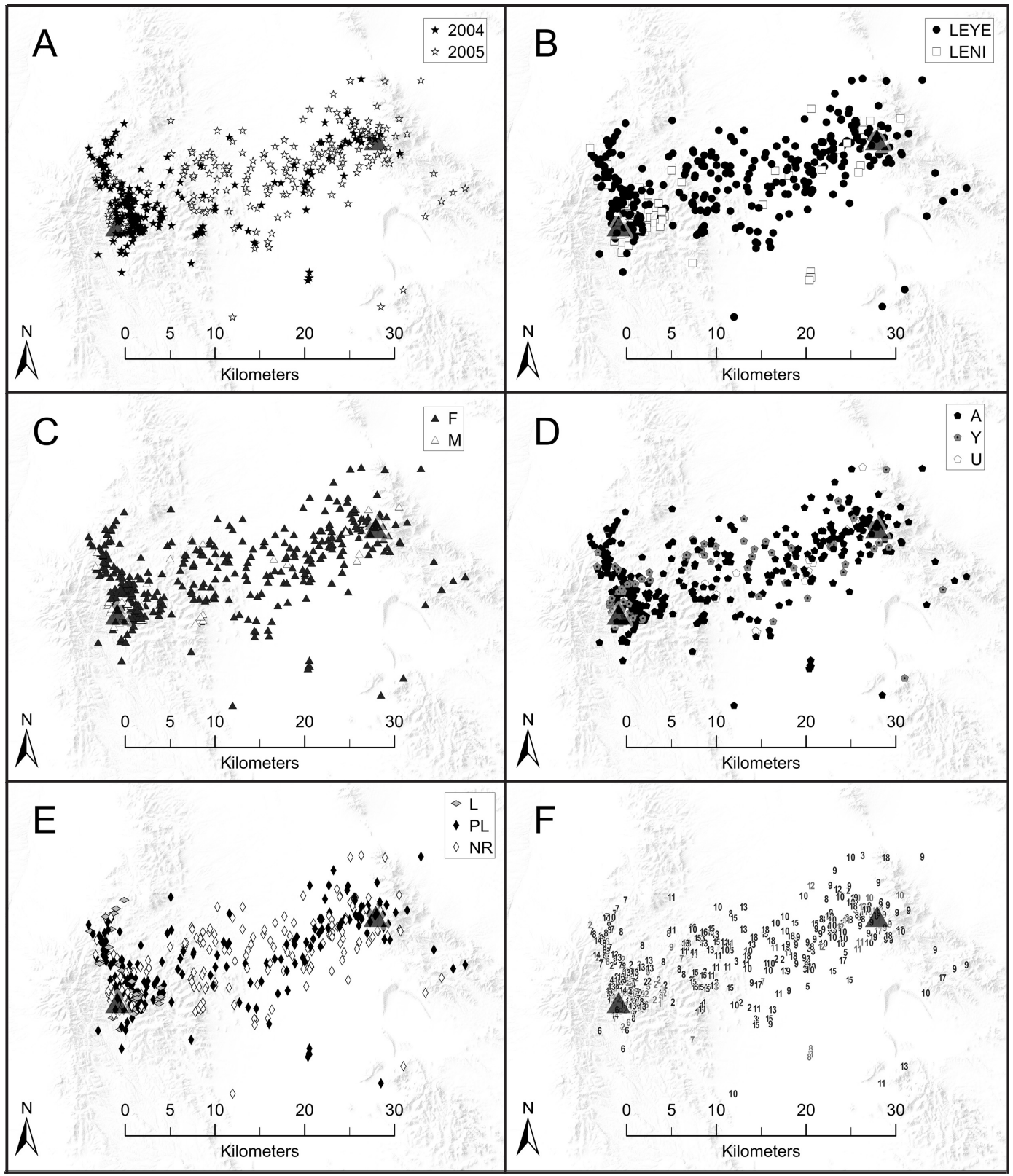

Fig. 4. Locations of Leptonycteris estimated from radiotelemetry data collected in mid-July through August of 2004 and 2005, by year, group, and individual. Both species were concurrently tracked between 19 July and 10 August in 2004, then between 19 July and 9 August in 2005. Panels display location estimates with error $\leq 10 \mathrm{~km}^{2}$ by $(\mathrm{A})$ year; (B) species, $\mathrm{LEYE}=$ L. yerbabuenae, $\mathrm{LENI}=$ L. nivalis; $(\mathrm{C})$ sex, $\mathrm{F}=$ female, $\mathrm{M}=$ male; $(\mathrm{D})$ age, $\mathrm{A}=$ adult, $\mathrm{Y}=$ young-of-year, $\mathrm{U}=$ unknown; $(\mathrm{E})$ reproductive status, $\mathrm{L}=$ lactating, $\mathrm{PL}=$ postlactating, $\mathrm{NR}=$ nonreproductive or unknown; and $(\mathrm{F})$ individual, numbers denote different individuals with black numbers representing $L$. yerbabuenae and gray numbers representing $L$. nivalis. Larger triangles show general locations of caves used as daytime roosts.

movement patterns. These findings differ somewhat from previous evidence that, at least in other areas where they co-occur in Mexico, $L$. yerbabuenae and $L$. nivalis tend to live and forage in different habitats (Baker and Cockrum 1966, Arita 1991, Ayala-Berdón et al. 2013).

Species of long-nosed bats have been observed using different habitats in many 
areas of Mexico where their distributions overlap, with $L$. yerbabuenae occurring more frequently at lower-elevation desert sites and L. nivalis occurring more often in higherelevation forests dominated by pine and oak (Baker and Cockrum 1966). Arita (1991) formally tested this hypothesis by analyzing the geographic distribution of occurrence records for both species in relation to patterns of climate and vegetation. Although that analysis did not find evidence of spatial segregation between the 2 species at broad geographic scales, significant differences were noted in the habitats used by each species, with $L$. nivalis indeed occurring more at higher elevations and in pine-oak forests (Arita 1991). Recent investigations show that $L$. nivalis may be physiologically adapted for living at higher elevations and in colder environments than L. yerbabuenae (Ayala-Berdón et al. 2013). There are large areas where the ranges of $L$. yerbabuenae and L. nivalis overlap (Fig. 1A), but information on the fine-resolution habitat use by sympatric species of long-nosed bats is sparse.

Although our sampling was limited, we did not see evidence of obvious differences in nightly movement patterns, activity timing, or general habitats used by L. nivalis and L. yerbabuenae in the study area, nor among sex, age, or reproductive groups within each species. Spatial or temporal partitioning of nectar resources may occur at finer-resolution scales than those we were able to observe in this study, but our results suggest common behaviors and shared resources during late summer in the study area. If $L$. yerbabuenae and $L$. nivalis roost and forage in close proximity during their late-summer occupancy of southwestern New Mexico, then such habitat sharing might be particular to the area we studied at the northern fringes of their overlapping ranges.

The importance of southwestern New Mexico to long-nosed bat populations is unknown. Captures associated with this and prior local work (e.g., Findley et al. 1975, Cook 1986, Hoyt et al. 1994) indicated that the study area is transiently occupied by adult female $L$. yerbabuenae and a considerable proportion of volant young. However, we captured a few adult males that may be associated with small groups of adult males occurring in the nearby $(<50 \mathrm{~km}$ to the NW) Chiricahua Mountains of southeastern Arizona during early summer
(Hayward and Cockrum 1971, Hinman 2003). Adult female $L$. nivalis and their young composed the majority of samples in our study, but we captured fewer L. nivalis than L. yerbabuenae individuals in late July and early August, and proportionately more of what we presumed were adult male $L$. nivalis (47\% of those classified as adult). This differs from observations at the only known transiently occupied colony in Texas where adult female L. nivalis and their young occur earlier in the summer (Ammerman et al. 2012). Moreover, adult males are rarely encountered and approximately $75 \%$ of individuals sampled are young (Ammerman et al. 2012). The high proportion of apparently adult male $L$. nivalis in New Mexico could be the result of sampling bias (few total captures), true differences in the natural histories of each species, and/or our inability to precisely assess the age of bats.

Age determination in live bats involves examining the degree of ossification in the wing joints, and this can be especially problematic in late summer, which is the time of year when long-nosed bats move into the study area. It is possible, if not likely, that some $L$. nivalis we classified as adult males were actually older young-of-year with welldeveloped wing joints. Such systematic bias would mean that a proportion of the $L$. nivalis we captured were born earlier in the season or developed more rapidly than other young $L$. nivalis and $L$. yerbabuenae we observed. Long-nosed bats show considerable variability in birth timing and annual abundance in northern areas (Hayward and Cockrum 1971, Ammerman et al. 2012). Therefore, it may be that young $L$. nivalis migrated into New Mexico from different maternity sites and/or after maturing to the point of being indistinguishable from adults. If this were the case, then the majority of $L$. yerbabuenae and $L$. nivalis transiently occurring in New Mexico during late summer could be bats born elsewhere in previous months that are accumulating energy for their first southward migration. The importance of habitats in southwestern New Mexico to long-nosed bat populations might become clearer when we know the true proportion of young-of-year bats occurring there. Until more accurate methods of assessing the ages of bats become available, we are left to speculate whether the study area accommodates individuals excluded to the fringes of 
their range, or if southern New Mexico provides essential seasonal habitat for certain demographic groups, such as young bats preparing to migrate.

One of the most prominent patterns to emerge from our radio-tracking study was that most activity of both species grouped into 2 general categories: directionally erratic yet concentrated movements in the Animas Mountains, and more dispersed and direct movement to and from the Big Hatchet Mountains across the Playas Valley. We interpret these movements as both species foraging most often in the Animas Mountains, while sometimes commuting $>20 \mathrm{~km}$ in each direction to reach that foraging area from another roost cave in a mountain range with fewer food resources. It is possible that bat activity went undetected or underdetected in other parts of the study area, though we occasionally monitored peripheral areas for signals of tagged bats without success.

Long-distance commutes to and from flowerrich foraging areas are well documented in long-nosed bats seasonally occupying other regions. In the Sonoran Desert of Mexico, reproductive female L. yerbabuenae regularly commuted $30-35 \mathrm{~km}$ from a maternity roost to foraging areas of columnar cactus blooms during spring and early summer, often using the same small (about $1 \mathrm{~km}^{2}$ ) foraging areas night after night (Sahley et al. 1993, Horner et al. 1998). Most observations of L. yerbabuenae in direct flight were made as bats moved from day roosts to foraging areas, similar to what we observed across the Playas Valley, whereas flight in foraging areas was characterized by more erratic flight paths (Horner et al. 1998), as we most often observed in the Animas Mountains. However, general patterns of nightly behavior by long-nosed bats may not be generalizable between regions with different food plants and flowering times. In an area of southeastern Arizona that is more similar to our study area, Ober et al. (2005) tracked the nightly movements of $37 \mathrm{~L}$. yerbabuenae as they fed on A. palmeri and found individuals commuting an average of about $19 \mathrm{~km}$ per night from their day roosts to foraging areas. In that study, bats sometimes ranged over areas larger than $50 \mathrm{~km}^{2}$, but core use areas (likely foraging areas) averaged less than $1 \mathrm{~km}^{2}$. Bats regularly used the same foraging areas, but sometimes changed foraging grounds when local flowers stopped producing nectar (Ober et al. 2005). Although we were not able to quantitatively determine food-plant densities or the home ranges and core use areas (samples not spatially or temporally consistent enough) of individuals necessary to demonstrate bat preference for foraging in the Animas Mountains, our findings are consistent with the tracking studies of $L$. yerbabuenae in both Arizona and Mexico, showing that bats commute long distances to consistently visit foraging areas with high densities of blooming flowers (Horner et al. 1998, Ober 2000, Ober et al. 2005).

Flowering times of food plants might influence the nightly activity patterns of longnosed bats. In the Sonoran Desert of Mexico, female $L$. yerbabuenae seemed to spend part of the early evening assessing the availability of columnar cactus flowers and delay feeding in earnest until nectar volume increased from around midnight to 02:00 (Horner et al. 1998). However, the nightly timing of nectar production in A. palmeri differs from that of columnar cactus, with peak nectar production occurring in the early evening (approximately 21:00) and then declining throughout the night (Slauson 2000). In Arizona, peak visitation rates to $A$. palmeri by $L$. yerbabuenae indeed coincided with the presumed period of maximum nectar production near dusk, then declined as the night progressed (Ober and Steidl 2004). We consistently detected both $L$. yerbabuenae and L. nivalis throughout our nightly tracking sessions, although detection rates for both species declined near the middle of the night (Fig. 3). We presume that much of this middleof-the-night decline was due to bats entering night roosts in caves or buildings where their radio signals were attenuated. We often radiodetected or visually observed both species night roosting in structures in the Animas Mountains during the hours around midnight. In other regions, L. yerbabuenae is known to night roost for extended periods between foraging bouts (Horner et al. 1998, Ober 2000). Location estimates from our study also suggest that both species consistently foraged in the early morning hours before returning to day roosts. It is possible that the arrival of L. yerbabuenae and L. nivalis to the study area during the later phases of flowering by $A$. palmeri (Scott 2004) is somehow related to nectar production and increased foraging efficiency in bats needing to feed all night 
and accumulate sufficient energy for southward migration.

Our tracking results suggest that L. yerbabuenae and L. nivalis shared commuting and foraging areas during this study, as well as exhibited similar nightly activity patterns. Considering the clear evidence that these species may exploit different resources and habitats in other areas of sympatry (Baker and Cockrum 1966, Arita 1991), future research could evaluate the possibility that sympatric species of long-nosed bats in New Mexico partition resources at finer spatial or temporal scales than we were able to discern with our coarse-resolution, qualitative analysis. We found it difficult to obtain a sufficient number of precise and temporally consistent location estimates for quantitative analysis, primarily due to the long distances that bats moved each night and the remoteness of the study area. The vast majority of the study area was inaccessible by roads, and tracking stations were typically situated in rugged wilderness that required 1-2 hours to reach on foot. This remoteness, combined with frequent nighttime lightning storms during the time when bats were present, limited the parts of the study area we could cover each night. Weatherrelated safety concerns also prevented us from using the best sites for tracking stations on several nights. Our sampling was additionally limited by the need to individually scan for multiple radio frequencies, resulting in inconsistent temporal sampling and missed opportunities to detect bats. Some of the logistical and safety constraints that we faced could be addressed in future studies by making use of new tracking technologies, such as satellite or GPS tags, digitally coded radio transmitters that allow for simultaneous monitoring of multiple signals, or automated radio tracking towers (e.g., Kays et al. 2011, Taylor et al. 2011), that might improve detectability across broader areas, minimize safety risks to tracking personnel, and more efficiently determine the seasonal presence of bats at roosts and foraging areas in different parts of the region. Combined with prior methods, new tracking advances could help gain the fine-scale movement data necessary to determine whether species of long-nosed bats compete or possibly cooperate in this unique area of seasonal sympatry occupied prior to southward migration.

\section{ACKNOWLEDGMENTS}

Funding for this study was provided by the Las Cruces Field Office of the U.S. Bureau of Land Management and the USGS Fort Collins Science Center. Helpful comments on earlier drafts of this manuscript were provided by $\mathrm{R}$. Rodriguez and an anonymous reviewer. Access to study sites was facilitated by the Animas Foundation/Diamond A Ranch, W. Hurt, W. McDonald, P. Young, W. Young, and staff of the Coronado National Forest. Thanks to J.S. Altenbach, B. Brown, B. Cavalier, D. Dalton, J. Barnitz, C. Durr, M. Guzman, M. Hakkila, L. Lewis, R. Lister, J. McCormick, J. Medina, R. Medellín, B. Merhege, L. Noakes, R. Sherwin, and S. Wolf for assistance with getting the effort underway. We greatly appreciate the efforts of the field crews: D. Alba, A. ChungMacCoubrey, D. Dominguez, A. England, A. Englert, J. Frederick, K. Geluso, T. Gonzalez, L. Harding, J. Hoffman, R. Ives, R. Jankowicz, R. Ligon, G. Lopez, J. Mink, T. Mollhagen, D. Neubaum, M. Neubaum, R. Orr, T. Orr, C. Ramotnik, R. Rodriguez, S. Skalak, J. Stewart, and K. Toledo. Any use of trade, firm, or product names is for descriptive purposes only and does not imply endorsement by the U.S. Government.

\section{Literature Cited}

AlDRIDGE, H.D.J.N., AND R.M. BRIGHAM. 1988. Load carrying and maneuverability in an insectivorous bat: a test of the 5\% "rule" of radio-telemetry. Journal of Mammalogy 69:379-382.

Ammerman, L.K., C.L. Hice, and D.J. Schmidly. 2012. Bats of Texas. Texas A\&M University Press, College Station, TX.

Ammerman, L.K., M. McDonough, H.I. Hristov, and T.H. Kunz. 2009. Census of the endangered Mexican long-nosed bat Leptonycteris nivalis in Texas, USA, using thermal imaging. Endangered Species Research 8:87-92.

ARITA, H.T. 1991. Spatial segregation in long-nosed bats, Leptonycteris nivalis and Leptonycteris curasoae in Mexico. Journal of Mammalogy 72:706-714.

Ayala-Berdón, J., R. Galicia, C. Flores-Ortiz, R.A. Medellín, and J.E. Schondube. 2013. Digestive capacities allow the Mexican long-nosed bat (Leptonycteris nivalis) to live in cold environments. Comparative Biochemistry and Physiology A 164:622-628.

BAKer, R.J., AND E.L. Cockrum. 1966. Geographic and ecological range of the long-nosed bats, Leptonycteris. Journal of Mammalogy 47:329-331.

BAKER, R.R. 1978. The evolutionary ecology of animal migration. Holmes \& Meier Publishers, New York, NY. 1012 pp.

Bogan, M.A., P.M. Cryan, C.D. Weise, and E.W. Valdez. 2017. Radio telemetry data on nighttime movements 
of two species of migratory nectar-feeding bats (Leptonycteris) in Hidalgo County, New Mexico, latesummer 2004 and 2005. U.S. Geological Survey data release. https://doi.org/10.5066/F7000101

Brown, D.E. 1994. Chihuahuan desertscrub. Pages 169179 in D.E. Brown, editor, Biotic communities of the Southwest. University of Utah Press, Salt Lake City, UT.

Brunet-Rossinni, A.K., and G.S. Wilkinson. 2009. Methods for age estimation and the study of senescence in bats. Pages 315-325 in T.H. Kunz and S. Parsons, editors, Ecological and behavioral methods for the study of bats. 2nd edition. Johns Hopkins University Press, Baltimore, MD.

Cockrum, E.L. 1991. Seasonal distribution of northwestern populations of the long-nosed bats Leptonycteris sanborni family Phyllostomidae. Anales del Instituto de Biologia, Universidad Nacional Autonoma de Mexico, Serie Zoologia 62:181-202.

COLE, F.R., AND D.E. WILSON. 2006. Leptonycteris yerbabuenae. Mammalian Species 797:1-7.

Cook, J.A. 1986. The mammals of the Animas Mountains and adjacent areas, Hidalgo County, New Mexico. Occasional Papers, Museum of Southwestern Biology 4:1-45.

Cryan, P.M., AND M.A. Bogan. 2003. Recurrence of Mexican long-tongued bats (Choeronycteris mexicana) at historical sites in Arizona and New Mexico. Western North American Naturalist 63:314-319.

Findley, J.S., A.H. Harris, D.E. Wilson, and C. Jones. 1975. Mammals of New Mexico. University of New Mexico Press, Albuquerque, NM.

FLeming, T.H. 2004. Nectar corridors. Migration and annual cycle of lesser long-nosed bats. Pages 23-42 in G.P. Nabhan, editor, Conserving migratory pollinators and nectar corridors in western North America. University of Arizona Press, Tucson, AZ.

Fleming, T.H., C.T. SAhley, J.N. Holland, J.D. Nason, AND J.L. Hamrick. 2001. Sonoran Desert columnar cacti and the evolution of generalized pollination systems. Ecological Monographs 71:511-530.

Fleming, T.H., T. Tibbetts, Y. Petryszyn, and M. Dalton VIRGINIA. 2003. Current status of pollinating bats in the southwestern United States. Pages 63-68 in T.J. O'Shea and M.A. Bogan, editors, Monitoring trends in bat populations of the United States and territories: problems and prospects. U.S. Geological Survey, Biological Resources Discipline, Information and Technology Report, USGS/BRD/ITR-2003-0003. 274 pp.

Gentry, H.S. 1982. Agaves of continental North America. University of Arizona Press, Tucson, AZ.

HaYward, B.J., AND E.L. Cockrum. 1971. The natural history of the western long-nosed bat, Leptonycteris sanborni. Western New Mexico University Research in Science 1:75-123.

Hensley, A.P., AND K.T. Wilkins. 1988. Leptonycteris nivalis. Mammalian Species 307:1-4.

Hinman, K.E. 2003. The nature of the mutualism between Agave palmeri and its bat pollinators (Leptonycteris curasoae and Choeronycteris mexicana) in southeastern Arizona. Doctoral dissertation, State University of New York, Stony Brook, NY.

Hoffmeister, D.F. 1986. Mammals of Arizona. University of Arizona Press, Tucson, AZ.

Holden, C. 2006. Report warns of looming pollination crisis in North America. Science 314:397.
Horner, M.A., T.H. Fleming, and C.T. SAhley. 1998. Foraging behaviour and energetics of nectar-feeding bat, Leptonycteris curasoae (Chiroptera: Phyllostomidae). Journal of Zoology (London) 244:575-586.

Hoyt, R.A., J.S. Altenbach, and D.J. Hafner. 1994. Observations on long-nosed bats (Leptonycteris) in New Mexico. Southwestern Naturalist 39:175-179.

Kays, R., S. Tilak, M. Crofoot, T. Fountain, D. Obando, A. Ortega, F. Kuemmeth, J. Mandel, G. Swenson, T. LAmbert, ET AL. 2011. Tracking animal location and activity with an automated radio telemetry system in a tropical rainforest. Computer Journal 54:1931-1948.

Kunz, T.H., R. Hodgkinson, And C.D. Weise. 2009. Methods of capture and handling bats. Pages 3-35 in T.H. Kunz and S. Parsons, editors, Ecological and behavioral methods for the study of bats. 2nd edition. Johns Hopkins University Press, Baltimore, MD.

LENTH, R.V. 1981a. On finding the source of a signal. Technometrics 23:149-154.

LENTH, R.V. 1981b. Robust measures of location for directional data. Technometrics 23:77-81.

Medellín, R.A. 2009. Sustaining transboundary ecosystem services provided by bats. Pages 170-187 in L. López-Hoffman, E.D. McGovern, R.G. Varady, and K.W. Flessa, editors, Conservation of shared environments: learning from the United States and Mexico. University of Arizona Press, Tucson, AZ.

Moreno-Valdez, A., W.E. Grant, and R.L. Honeycutt. 2000. A simulation model of Mexican long-nosed bat (Leptonycteris nivalis) migration. Ecological Modelling 134:117-127.

Moreno-Valdez, A., R.L. Honeycutt, and W.E. Grant. 2004. Colony dynamics of Leptonycteris nivalis (Mexican long-nosed bat) related to flowering Agave in northern Mexico. Journal of Mammalogy 85: 453-459.

NABHAN, G.P. 2004. Stresses on pollinators during migration: is nectar availability at stopovers the weak link in plant-pollinator conservation? Pages 3-22 in G.P. Nabhan, editor, Conserving migratory pollinators and nectar corridors in western North America. Arizona-Sonora Desert Museum Studies in Natural History. University of Arizona Press, Tucson, AZ.

NabHan, G.P., AND T.H. Fleming. 1993. Conservation of New World mutualisms. Conservation Biology $7: 457-462$.

NAms, V.O. 1990. LOCATE II user's guide. Pacer, Truro, Nova Scotia, Canada.

NAMS, V.O., AND S.A. BouTin. 1991. What is wrong with error polygons. Journal of Wildlife Management 55:172-176.

OBeR, H.K. 2000. Foraging ecology of lesser long-nosed bats. Master's thesis, University of Arizona, Tucson, AZ.

Ober, H.K., And R.J. STEIDL. 2004. Foraging rates of Leptonycteris curasoae vary with characteristics of Agave palmeri. Southwestern Naturalist 49:68-74.

Ober, H.K., R.J. SteidL, and V.M. Dalton. 2005. Resource and spatial-use patterns of an endangered vertebrate pollinator, the lesser long-nosed bat. Journal of Wildlife Management 69:1615-1622.

O’Shea, T.J., AND M.A. Bogan, EDITORS. 2003. Monitoring trends in bat populations of the United States and territories: problems and prospects. U.S. Geological Survey, Biological Resources Discipline, Information and Technology Report, USGS/BRD/ITR-2003-0003. $274 \mathrm{pp}$. 
RaCEY, P.A. 2009. Reproductive assessment of bats. Pages 249-264 in T.H. Kunz and S. Parsons, editors, Ecological and behavioral methods for the study of bats. 2nd edition. Johns Hopkins University Press, Baltimore, MD.

Sahley, C.T., M.A. Horner, and T.H. Fleming. 1993. Flight speeds and mechanical power outputs of the nectar-feeding bat, Leptonycteris curasoae (Phyllostomidae, Glossophaginae). Journal of Mammalogy 74:594-600.

SCOTT, P.E. 2004. Timing of Agave palmeri flowering and nectar-feeding bat visitation in the Peloncillos and Chiricahua Mountains. Southwestern Naturalist 49:425-434.

Sikes, R.S., W.L. Gannon, and the Animal Care and Use Committee of the AMERICAN Society of MammaloGISTS. 2011. Guidelines of the American Society of Mammalogists for the use of wild mammals in research. Journal of Mammalogy 92:235-253.

Slauson, L.A. 2000. Pollination biology of two chiropterophilous agaves in Arizona. American Journal of Botany 87:825-836.
Taylor, P.D., S.A. Mckenzie, B.G. Thurber, A.M. Calvert, A.M. Mills, L.P. McGuire, and C.G. Guglielmo. 2011. Landscape movements of migratory birds and bats reveal an expanded scale of stopover. PLOS ONE 6:e27054.

Valiente-Banuet, A. 2002. Vulnerability of pollination systems of columnar cacti of Mexico. Revista Chilena De Historia Natural 75:99-104.

Wilkinson, G.S., AND T.H. Fleming. 1996. Migration and evolution of lesser long-nosed bats Leptonycteris curasoae, inferred from mitochondrial DNA. Molecular Ecology 5:329-339.

Wilson, D.E., AND D.M. ReEder. 2005. Mammal species of the world: a taxonomic and geographic reference. Smithsonian Institution Press, Washington, DC.

Received 16 September 2016 Accepted 31 July 2017

Published online 25 September 2017 